\title{
Structural consolidation of the Apostle Santiago's church in Jerez de la Frontera (Cádiz, Spain)
}

\author{
E. Rodríguez-Mayorga, E. Yanes \& A. Sáez \\ Department of Continuum Mechanics and Structural Analysis, \\ University of Sevilla, Spain
}

\begin{abstract}
The Church of Santiago, in Jerez de la Frontera (Cádiz, Spain), is a three-nave temple with a basilican plan built in the 15 th century. The dimensions of the current plan are approximately $43 \times 25 \mathrm{~m}^{2}$ with a height of $20 \mathrm{~m}$ at the central nave. The church has undergone several modifications through history, either to enlarge its plan or to restore it, so that different styles are present, gothic being the most significant one. All the changes introduced to the original project have given rise to an irregular geometry. This fact plus a deteriorated material due mainly to rising damp, has caused severe structural problems. These structural problems have led to the closure of the church in 2005.

The aims of this paper are the repair and strengthening of the structure of the temple. To achieve it, two facts are proposed: mineralization of the stone to avoid the effect of rising damp, and restoration of the original stiffness of the stone by consolidating them.
\end{abstract}

Keywords: historical masonry building, FE modelling, consolidation, grout injection, NDT.

\section{Introduction}

The Church of Santiago is one of the main temples in the city of Jerez de la Frontera (Spain). It was built as a three-nave church at the end of the $15^{\text {th }}$ century, but some elements were added after the end of the construction in order to enlarge it. An exhaustive historic study can be found in the works of Ríos Martínez [6] and Álvarez Luna et al. [1]. Nowadays the structure has an approximate size of $43 \times 25 \mathrm{~m}^{2}$ in plan and $20 \mathrm{~m}$. of maximum height (fig 1). 

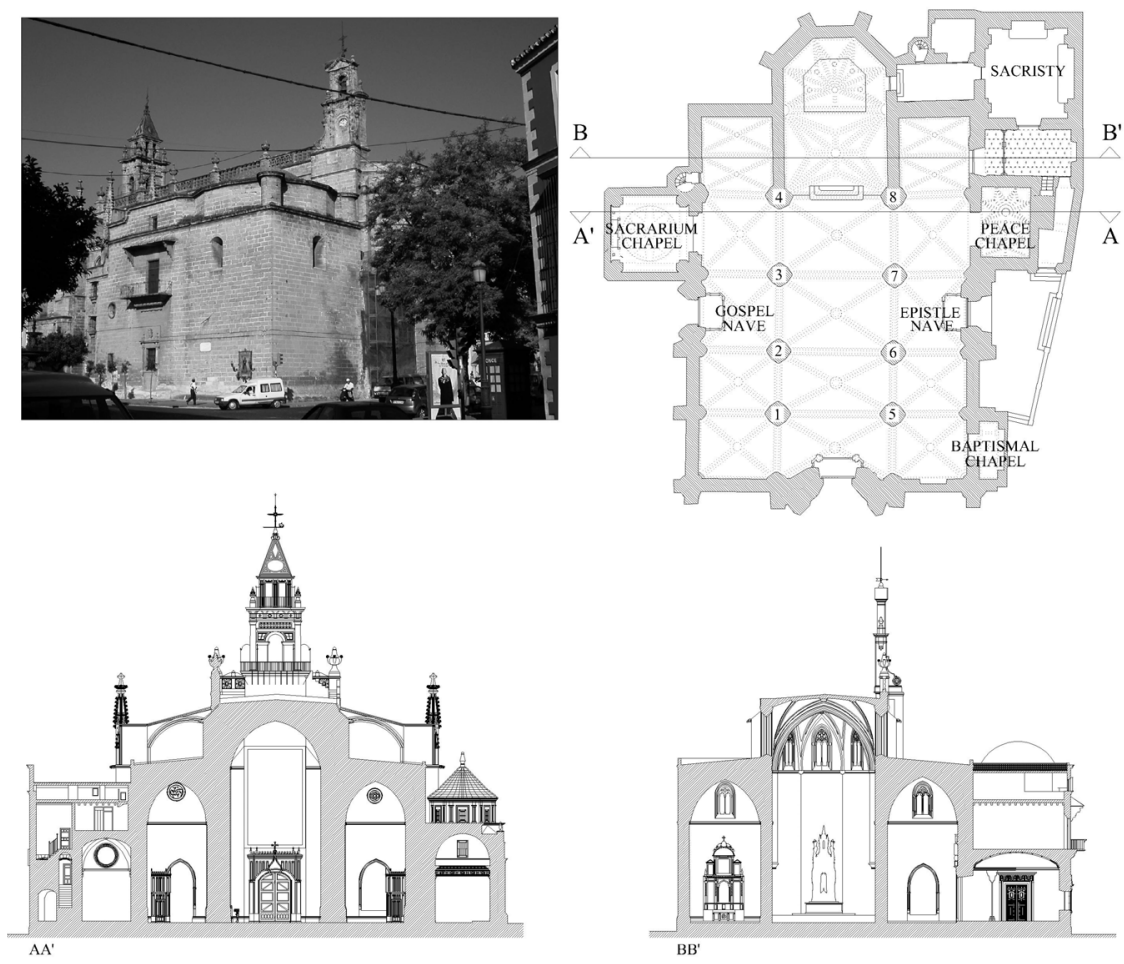

Figure 1: Geometry of the Church of Santiago Apostle.

The temple has suffered severe structural problems along its history. The first documented problem dates from 1695, when columns 2 and 3 collapsed (fig 1), and were immediately reconstructed. In 1905 column number 1 was substituted using better-quality sandstone, in order to avoid a new catastrophe. In 1928 the lower part of column number 7 was substituted as well. In 1956, during some repairing works column number 6 and the adjacent vaults collapsed. Some years later, column number 6 was rebuilt using the original stone filled with reinforced concrete, and column number 8 was filled with concrete.

All the renovation, enlargement and reconstruction works that have taken place along the history have produced an irregular geometry and an irregular stiffness distribution, the second one caused by the heterogeneity of materials: the majority of piers and walls are made with soft sandstone and a core of rubble masonry, but some piers were rebuilt using a better-quality stone as well as concrete.

In 2004 the structure showed new symptoms of structural problems. These symptoms mainly affected the area around the baptismal chapel and column number 5 (fig 2). This fact led to the closure of the temple in 2005. 

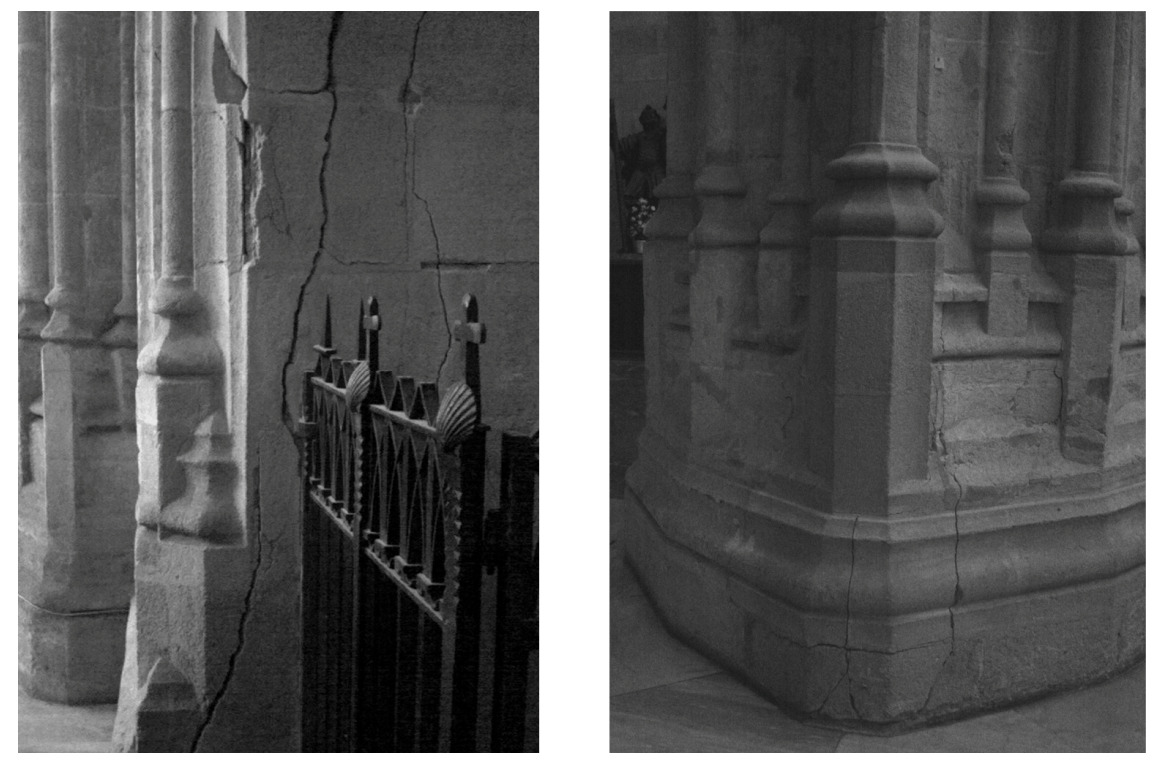

Figure 2: Damage on the walls of the Baptismal chapel (left) and on the basement of column 5 (right).

Detailed investigations have been carried out since then to assess the structural integrity of the monument: tests to characterize the physicalmechanical properties of materials, to evaluate the soil and the current state of the foundations, etc. A finite element model for the static analysis of the church was developed as well to help in understanding the behaviour of the church and to evaluate the expected impact of the restoration measures adopted.

In this paper the technical solution implemented to repair and strengthen the structural system of the church is described thoroughly. Such solution is based on two aims: minimize the effect of rising damp by mineralization of the original stone and consolidate the structure by grout injection of the pillars and walls.

\section{Diagnosis}

\subsection{Tests}

Several on-site tests were conducted to assess the current condition of the main structure and its foundations, including rising damp measures, coring from several structural elements, videoscopes of pier's cores, boreholes to characterize the soil, ultrasonic tomography to obtain mechanical properties of materials, georadar, etc.

The results from all these tests are described in Rodríguez-Mayorga et al. [7]. The main conclusions out of such tests, and a detailed study of the geometry of the temple were that: (a) the problem was not relative to foundations; (b) rising 
damp has an effect of deterioration in the stone, shortening the value of the Young Modulus up to $30 \%$; (c) mechanical properties of stone are obtained; (d) unbalanced geometry as a result of the additive process that have given rise to the temple.

\subsection{Structural analysis by a finite element model}

A simplified finite element model, with shell and beam elements (fig 3), was carried out with Ansys in order to achieve a better understanding of the behaviour of the structure (Lourenço et al. [5]). Only gravitational loads were taken into account since the temple is located at a low-risk seismic zone.

All the known geometrical and material irregularities were introduced into the model. The values of the material parameters for a linear elastic analysis were obtained through tests mentioned previously. In particular, different Young modulus values were considered for the lower and upper (above $2.00 \mathrm{~m}$.) part of the piers to account for the material degradation due to rising damp (table 1).
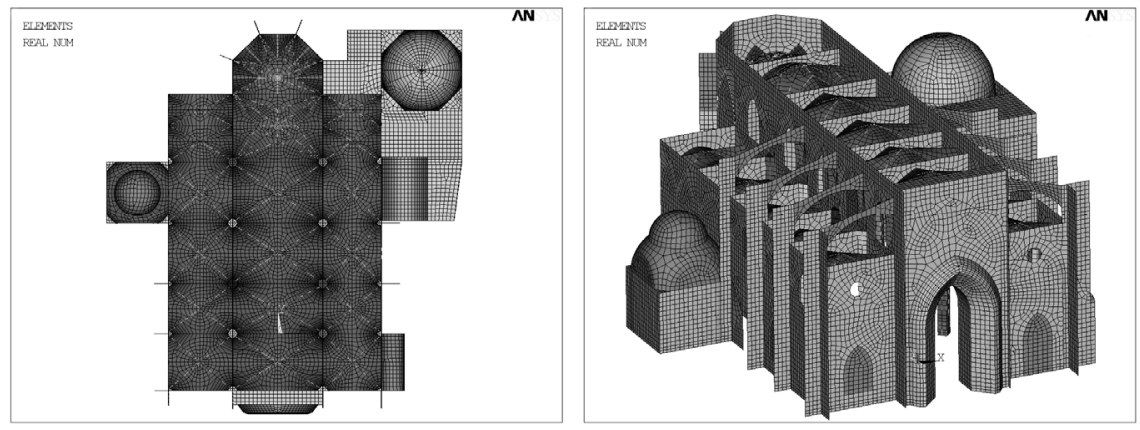

Figure 3: $\quad$ Two views of the EF model

Table 1: $\quad$ Properties applied to the model.

\begin{tabular}{|c|c|c|c|c|c|}
\hline & \multicolumn{2}{|c|}{ E piers $\left(\mathrm{N} / \mathrm{mm}^{2}\right)$} & $E\left(\mathrm{~N} / \mathrm{mm}^{2}\right)$ & & \\
\cline { 5 - 6 } & Between 0-2 m. & Above $2 \mathrm{~m}$ & Pier's filling & $v$ & $\gamma\left(\mathrm{kN} / \mathrm{m}^{3}\right)$ \\
\hline 1 & 13470 & 14550 & 14550 & 0.25 & 20 \\
\hline 2 & 6570 & 10100 & 2000 & 0.25 & 18 \\
\hline 3 & 7720 & 8770 & 2000 & 0.25 & 18 \\
\hline 4 & 7400 & 7860 & 2000 & 0.25 & 17 \\
\hline 5 & 3835 & 5520 & 2000 & 0.25 & 17 \\
\hline 6 & 7250 & 8200 & 8200 & 0.25 & 20 \\
\hline 7 & 6320 & 6000 & 2000 & 0.25 & 18 \\
\hline 8 & 8230 & 6460 & 2000 & 0.25 & 20 \\
\hline Walls, vaults & 6000 & 6000 & 2000 & 0.25 & 18 \\
\hline
\end{tabular}

Figure 4 shows the displacements obtained along $\mathrm{X}$ axis (normal to the naves) in plan. Due to the irregular geometry of the church (fig 1), the structure presents asymmetric displacements, with a movement towards the Gospel-nave side, as expected. 
The distribution of compressive stresses (fig 5) is also asymmetric, with significantly different values at piers in both sides of the church. These values are different too among different piers according to their stiffnesses. Compressive stresses values are larger in piers number 1 and number 6 . The rest of the piers show smaller values, but the resistance of the stone is lower too.

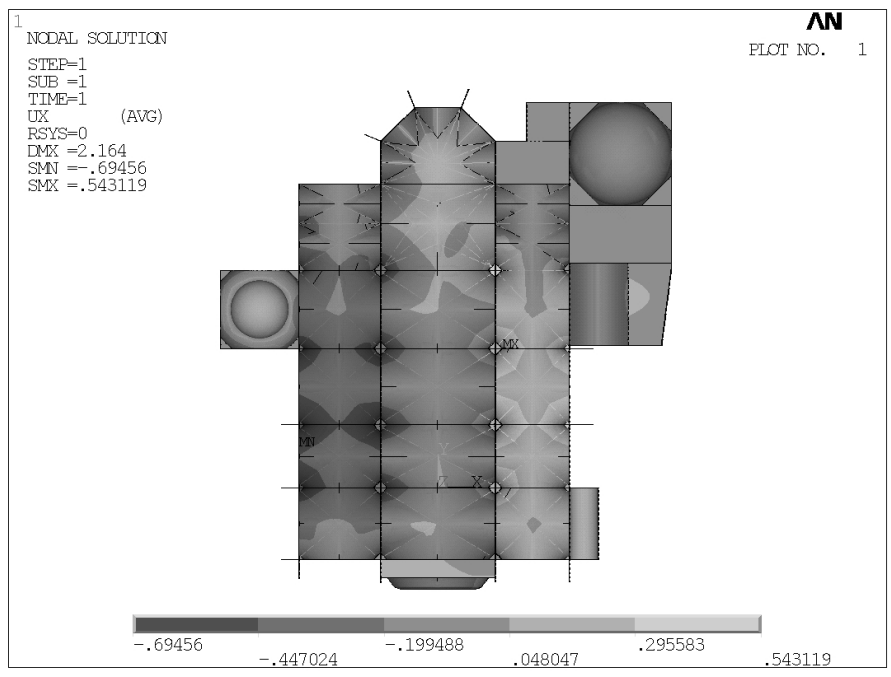

Figure 4: Displacements along $\mathrm{X}$ axis $(\mathrm{mm})$

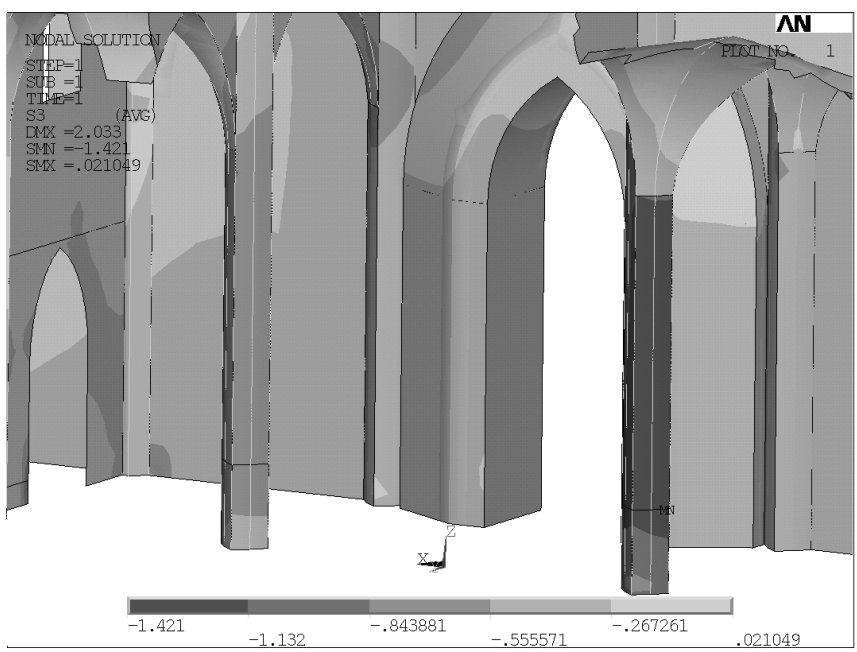

Figure 5: Compressive principal stresses in Baptismal Chapel and piers 5 and $1\left(\mathrm{~N} / \mathrm{mm}^{2}\right)$. 


\section{Restoration}

The restoration measures adopted will aim at: (a) improving the mechanical properties of the material; (b) reducing the impact of rising damp on material degradation.

The first objective will be addressed by grout injection (Ignoul et al. [4], Van Rickstal [9], Toumbakari [8], Binda et al. [2]) of columns and walls, and the second one by mineralization of the stone.

\subsection{Strengthening the structure by grout injection}

The proposed solution is to inject all the piers (except for pier 1) and the most damaged walls (fig 6). In this way the mechanical properties of those structural elements will be improved and a more homogeneous stiffness distribution in the structure will result.

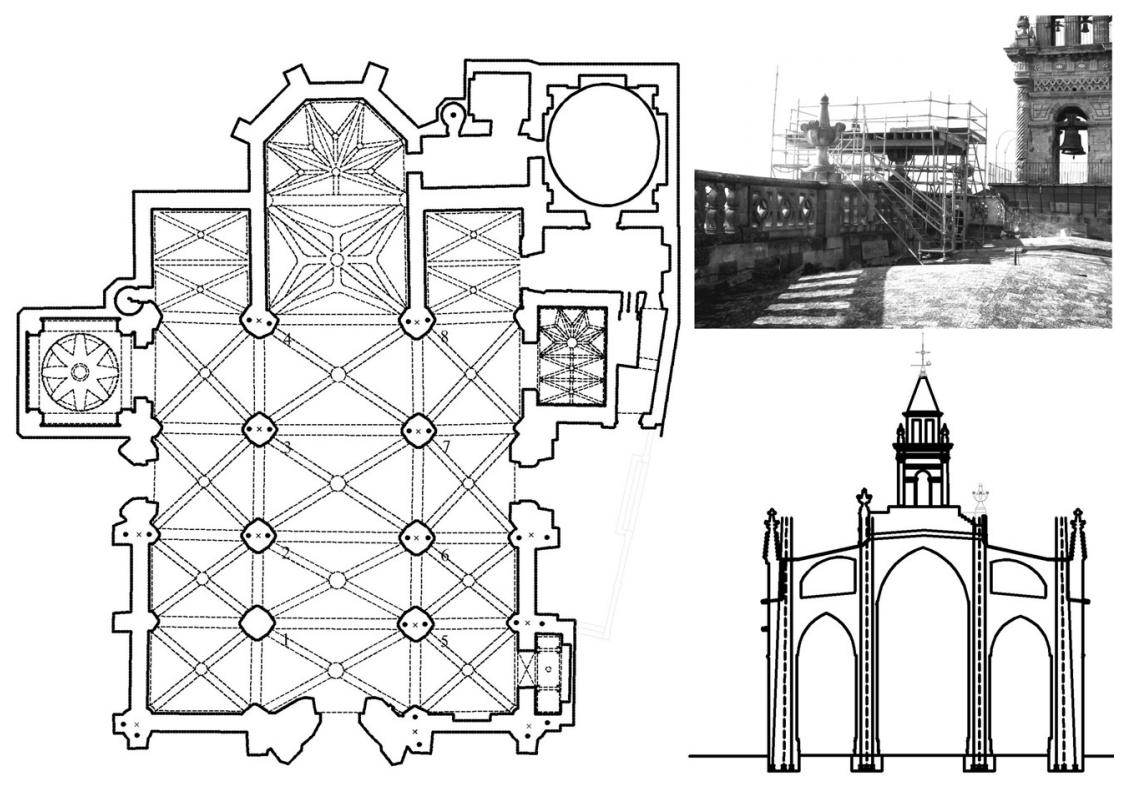

Figure 6: Scheme of injection placement; scaffold board prepared for beginning the works and scheme of vertical injections.

In fact, in considering the F. E. model that the material properties coincide with those of pier 1, a more homogeneous stress distribution will be obtained, as fig. 7 shows. In this situation, all piers would have a similar behaviour and acceptable safety coefficients (table 2), for compressive resistance of $3.62 \mathrm{~N} / \mathrm{mm}^{2}$. The stress distribution and deformed shape would not be totally symmetrical because of the irregular geometry, but the values of the maximum stresses would have only a $5 \%$ of deviation, smaller than the $20 \%$ observed before. 


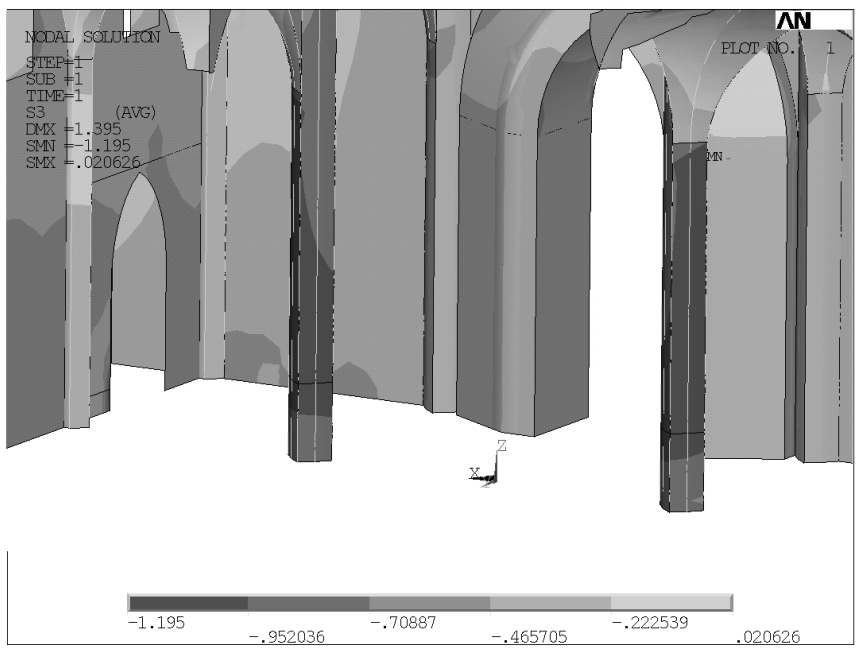

Figure 7: Compressive principal stresses in Baptismal Chapel and piers 5 and 1 after consolidation $\left(\mathrm{N} / \mathrm{mm}^{2}\right)$.

Table 2: Comparative resistance values before and after the consolidation resulting from the F. E. model.

\begin{tabular}{|c|c|c|c|c|c|}
\cline { 2 - 6 } \multicolumn{1}{c|}{} & \multicolumn{3}{c|}{ Pre-treatment values } & \multicolumn{2}{c|}{ Post-treatment values } \\
\hline Pier & $\begin{array}{c}\text { Compressive } \\
\text { resistance } \\
\left(\mathrm{N} / \mathrm{mm}^{2}\right)\end{array}$ & $\begin{array}{c}\text { Maximum } \\
\text { compressive } \\
\text { stress } \\
\left(\mathrm{N} / \mathrm{mm}^{2}\right)\end{array}$ & $\begin{array}{c}\text { Safety } \\
\text { coefficient }\end{array}$ & $\begin{array}{c}\text { Maximum } \\
\text { compressive } \\
\text { stress } \\
\left(\mathrm{N} / \mathrm{mm}^{2}\right)\end{array}$ & $\begin{array}{c}\text { Safety } \\
\text { coefficient }\end{array}$ \\
\hline 1 & 3,62 & 1,42 & 2,54 & 1,20 & 3,02 \\
\hline 2 & 1,43 & 1,18 & 1,21 & 1,08 & 3,34 \\
\hline 3 & 1,28 & 1,24 & 1,03 & 1,08 & 3,34 \\
\hline 4 & 1,17 & 1,00 & 1,17 & 1,08 & 3,33 \\
\hline 5 & 1,16 & 1,14 & 1,02 & 1,12 & 3,23 \\
\hline 6 & 4,33 & 1,40 & 3,08 & 1,17 & 3,70 \\
\hline 7 & 1,26 & 1,10 & 1,14 & 1,16 & 3,12 \\
\hline 8 & 8,15 & 1,03 & 7,93 & 1,19 & 6,87 \\
\hline
\end{tabular}

The initial step was the placement of scaffoldings to discharge the piers (fig 8). To place these elements, consolidation of the soil was necessary because of its low resistance. This was achieved by injection of a mixture of cement, bentonite and water.

The injection for reinforcing the stone was divided into two phases: (a) injection of the exterior parts of the columns and (b) injection of the core of the columns. In parallel with these, the injection of the walls of the Baptismal Chapel.

All the grouts have microcement as the binder agent, water, and a plastificant additive too for avoiding the flocculation. 


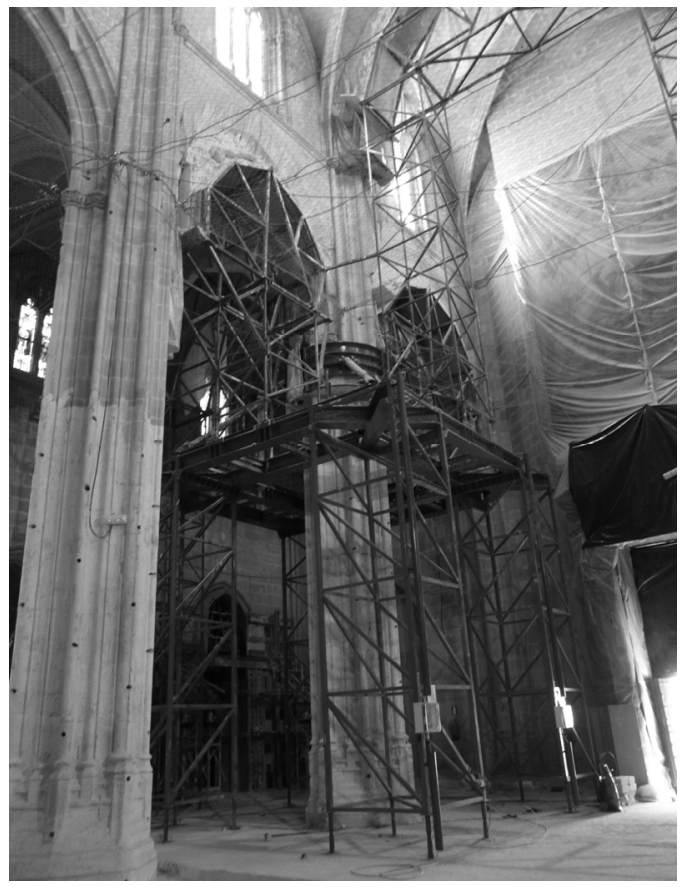

Figure 8: Scaffoldings designed to discharge the piers.

\subsubsection{Injection of the exterior part of the columns}

Previous to the injection an exterior steel encasement filled with plaster was placed for avoiding lateral expansion of the piers (fig 9). Only the six lowest meters of each pier were injected. For this, a matrix of holes in alternate placements was drilled (fig 8).

After the exterior injection was finished, new values of the stone properties were taken. After this part of the reinforcement, about the $80 \%$ of the aimed final value is achieved (table 3 ).
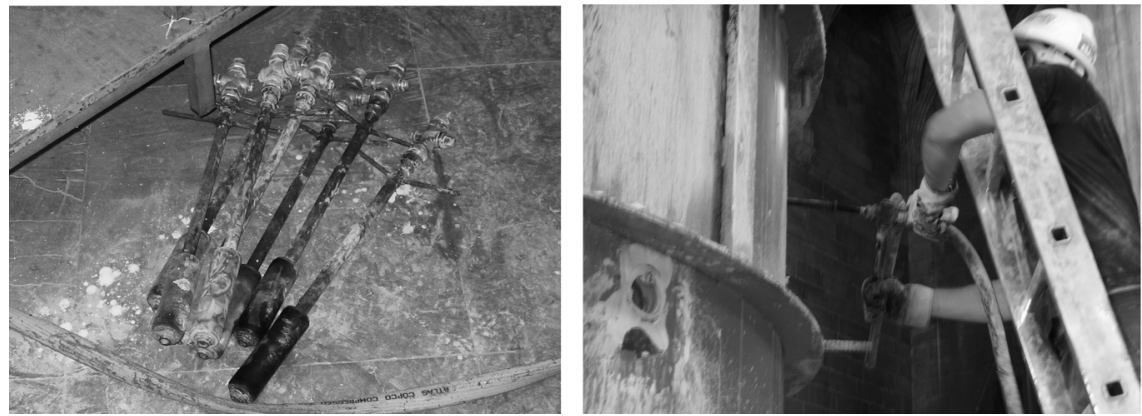

Figure 9: Valves and process of injection with the steel encasement. 
Table 3: $\quad$ Values of Young Modulus.

\begin{tabular}{|c|c|c|c|c|c|}
\hline \multirow{2}{*}{ Pier } & $\begin{array}{c}\text { Level } \\
(\mathrm{m})\end{array}$ & $\begin{array}{c}\text { Pre-injection } \\
\text { Modulus } \\
(\mathrm{MPa})\end{array}$ & $\begin{array}{c}\text { Post-injection } \\
\text { Modulus } \\
(\mathrm{MPa})\end{array}$ & $\begin{array}{c}\text { Percentage of } \\
\text { improvement }\end{array}$ & $\begin{array}{c}\text { Percentage } \\
\text { of the goal }\end{array}$ \\
\hline \multirow{2}{*}{1} & 2.00 & 13470 & - & - & - \\
\cline { 2 - 6 } & 6.00 & 14550 & - & - & - \\
\hline \multirow{2}{*}{2} & 2.00 & 6570 & 9760 & $149 \%$ & $67 \%$ \\
\cline { 2 - 6 } & 6.00 & 10100 & 11300 & $112 \%$ & $78 \%$ \\
\hline \multirow{2}{*}{3} & 2.00 & 7720 & 10370 & $134 \%$ & $71 \%$ \\
\cline { 2 - 6 } & 6.00 & 8770 & 11000 & $125 \%$ & $76 \%$ \\
\hline \multirow{2}{*}{4} & 2.00 & 7400 & 11250 & $152 \%$ & $77 \%$ \\
\cline { 2 - 6 } & 6.00 & 7860 & 10275 & $131 \%$ & $71 \%$ \\
\hline \multirow{2}{*}{5} & 2.00 & 3835 & 8260 & $215 \%$ & $57 \%$ \\
\cline { 2 - 6 } & 6.00 & 5520 & 8838 & $160 \%$ & $61 \%$ \\
\hline \multirow{2}{*}{6} & 2.00 & 7250 & 10920 & $151 \%$ & $75 \%$ \\
\cline { 2 - 6 } & 6.00 & 8200 & 10838 & $132 \%$ & $74 \%$ \\
\hline \multirow{2}{*}{7} & 2.00 & 6320 & 8910 & $141 \%$ & $61 \%$ \\
\cline { 2 - 6 } & 6.00 & 6000 & 8188 & $136 \%$ & $56 \%$ \\
\hline \multirow{2}{*}{8} & 2.00 & 8230 & 11890 & $144 \%$ & $82 \%$ \\
\cline { 2 - 6 } & 6.00 & 6460 & 10913 & $169 \%$ & $75 \%$ \\
\hline
\end{tabular}

\subsubsection{Injection of the core of the columns}

The injections to consolidate the core of the piers and some walls will be vertical, along the whole element, and there will be three of them in each pier, except for the column number 1 (fig 6). With this second phase of the consolidation, the mechanical properties of pier 1 are expected to be achieved.

\subsection{Avoiding rising damp}

The analysis has revealed that moisture has shortened the values of the Young Modulus around a 10\% (table 1).

According to Heiman [3], grout injections can avoid the effect of moisture in buildings, but not rising damp. Injection of a mineralizator was chosen as the way of avoiding the problem.

The application of the mineralization product is going to be at the end of the process and with the gravitational pressure. The impregnation of all the walls and pier's basements will be through several holes in an alternate order. Each hole will cross only half the section of the wall.

\section{Conclusions}

This paper presents the case study of the church of Santiago in Jerez de la Frontera (Spain). This church was affected by some collapses in the past and showed deep deterioration recently, caused mainly by its irregular geometry and the effect of rising damp over the ashlars. This paper describes the restoration works in progress to consolidate the structure through: (a) mineralization of the stone, to control the effect of rising damp; and (b) grout injection of piers and walls. 
A F. E. model was developed in order to better understand the structural behaviour of the church, as well as the expected impact of some of the proposed remedial measures.

Some preliminary tests of the consolidated structure have been presented.

\section{References}

[1] Álvarez Luna, A., Guerrero Vega, J. \& Romero Bejarano M. Intervention in heritage. Churches in Jerez case (1850-2000) (In Spanish). Servicio de publicaciones. Ayuntamiento de Jerez, 2003.

[2] Binda, L., Modena, C., Baronio, G. \& Abbaneo. Repair and investigation techniques for stone masonry walls. Construction and Building Materials, 11(3), pp. 132-142, 1997.

[3] Heiman, J. L. An Evaluation of Methods of Treating Rising Damp, Proc. of the symposium Moisture Migration in Buildings, eds. M. Lieff \& H. R. Trechsel, American Society for Testing and Materials, pp. 121-127, 1982.

[4] Ignoul, F., Van Rickstal, F. \& Van Gemert, D. Application of mineral grouts. Case study and impact on structural behaviour: Church of St. Cathalina at Duisburg (B). Proc. of the IV International Seminar on Structural Analysis of historical constructions. Possibilities of numerical and experimental techniques, eds C. Modena, P. B. Lourenço \& P. Roca, Padova, 2004.

[5] Lourenço, P.B., Krakowiak, K.J., Fernandes, F.M., \& Ramos, L.F. Failure analysis of Monastery of Jeronimos, Lisbon: How to learn from sophisticated numerical models. Engineering Failure Analysis 14, pp. 280300, 2007.

[6] Rios Martinez, E. Antón Martín Calafate and Diego Moreno Meléndez in 17 th century architecture in Jerez (in Spanish). Servicio de publicaciones Universidad de Cádiz, 2002.

[7] Rodríguez-Mayorga, E., Yanes, E., Compán, V. \& Sáez, A. Rehabilitation of The Church of Santiago (Jerez de la Frontera, Spain). A case study. Proc. of Heritage 2008 International Conference World Heritage and Sustainable Development, eds Rogério Amoêda, Sérgio Lira, Cristina Pinheiro, Filipe Pinheiro and João Pinheiro, pp 825-833, 2008.

[8] Toumbakari, E-E., Lime-pozzolan-cement grouts and their Structural effects on composite masonry walls. PhD Dissertation, Katholieke Universiteit, Leuven, 2001.

[9] Van Rickstal, F., Grout injection of masonry, scientific approach and modeling. Ph. D Thesis. Dept of Civil Engineering, Katholieke Universiteit, Leuven, 2000. 